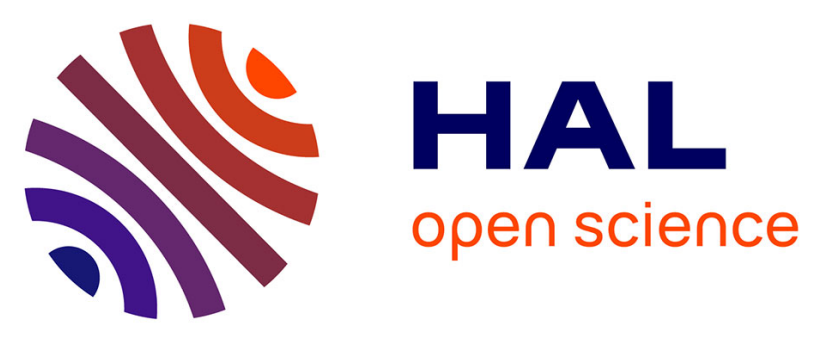

\title{
Kinetics and efficiency of Plasmodium falciparum development in the midguts of Anopheles gambiae, An. funestus and An. nili
}

Vincent Robert, Gilbert Le Goff, Louis-Clément Gouagna, M Sinden, J Kieboom, R Kroneman, Jan Peter Verhave

\section{To cite this version:}

Vincent Robert, Gilbert Le Goff, Louis-Clément Gouagna, M Sinden, J Kieboom, et al.. Kinetics and efficiency of Plasmodium falciparum development in the midguts of Anopheles gambiae, An. funestus and An. nili. Annals of Tropical Medicine and Parasitology, 1998, 92 (1), pp.115-118. 10.1080/00034983.1998.11813268 . hal-03363159

\section{HAL Id: hal-03363159 \\ https://hal.science/hal-03363159}

Submitted on 5 Oct 2021

HAL is a multi-disciplinary open access archive for the deposit and dissemination of scientific research documents, whether they are published or not. The documents may come from teaching and research institutions in France or abroad, or from public or private research centers.
L'archive ouverte pluridisciplinaire HAL, est destinée au dépôt et à la diffusion de documents scientifiques de niveau recherche, publiés ou non, émanant des établissements d'enseignement et de recherche français ou étrangers, des laboratoires publics ou privés. 


\section{Kinetics and efficiency of Plasmodium falciparum development in the midguts of Anopheles gambiae, An. funestus and An. nili}

The early sporogonic development of Plasmodium occurs in the lumen of the anopheline midgut and involves gametes, zygotes and ookinetes. An immunofluorescent method, using a monoclonal antibody $(\mathrm{MoAb})$ specific for the $25-\mathrm{kDa}$ protein (Pfs-25) expressed on the $P$. falciparum gamete-ookinete surface, may be used to detect infected mosquitoes in the field (Robert et al., 1995). In the present study, the same method has been used to evaluate the densities and determine the stages of $P$. falciparum in the midguts of naturally infected anophelines within $30 \mathrm{~h}$ of the infective bloodmeal on gametocyte carriers.

The holo-endemic study site was the hamlet of Ndonzengue, near the village of Mbebe $\left(4^{\circ} \mathrm{N}, 11^{\circ} \mathrm{E}\right)$, Cameroon, in the rainforest bordered by the Sanaga river. Anopheles gambiae s.s. was the only species of the An. gambiae complex present. Wild anopheline mosquitoes were collected at night just after they had fed on one of four $P$. falciparum gametocyte carriers, using a transparent tube $(8 \times 1 \mathrm{~cm})$ for each fly, and then maintained at $27.5 \pm 0.5^{\circ} \mathrm{C}$. Midguts were dissected at various times postbloodmeal (pbm), homogenized, mixed with the labelled Pfs-25 MoAb and completely screened, between slide and coverslip, with a fluorescent light microscope (Robert et al., 1995) and always within 45 min of dissection.

As the kinetics of the early sporogonic cycle of $P$. falciparum were similar in all three mosquito species studied (i.e. An. gambiae s.s.; $A n$. funestus; and $A n$. nili), the results presented here (Fig.) are pooled for all 351 anophelines investigated.

Although no round forms were observed before $20 \mathrm{~min}$ pbm (probably because the Pfs25 protein is not expressed on the gametocyte surface), they were observed in the midgut lumen from $30 \mathrm{~min} \mathrm{pbm}$, in about $80 \%$ of the anophelines. Round forms still represented a large proportion of stained parasites in mos- quitoes dissected 14-18 h pbm, perhaps then corresponding to microgametocytes (usually $25 \%$ of all gametocytes) or to unfertilised macrogametes, but were not found $>27 \mathrm{~h}$ pbm. The protruding round forms known as retorts or pre-ookinetes were observed from $6 \mathrm{~h} \mathrm{pbm}$ but decreaséd in abundance (as a percentage of stained parasites) from $13 \mathrm{~h}$, supporting the idea that the round-formretort transformation does not occur after $13 \mathrm{~h}$. Ookinetes were first seen at $12 \mathrm{~h} \mathrm{pbm}$, increased in abundance up to $16 \mathrm{~h}$ and then decreased in abundance from $20 \mathrm{~h}$. These observations agree with those of Garnham (1966), who stated that ookinete formation took 12-18 h, and those of Robert et al. (1995), who deduced that ookinetes would appear at $12-15 \mathrm{~h}$ and did not observe any ookinetes in gravid anophelines.

In immunofluorescent method used, the stained parasites remain alive and apparently continue their normal development, even when removed from the mosquito midgut. In the present study, some round-form-retort and retort-ookinete transformations were observed under the microscope, between slide and coverslip.

The development of the wild strains of malarial parasites observed in the present study appeared to be very fast compared with that observed with the NF54 strain which has been maintained in vitro; ookinetes of the latter strain only appear 24 (Meis et al., 1992; Chege and Beier, 1994) or even 31 h (Vaughan et al., 1992) pbm.

There appear to be optimal times pbm for detecting particular stages of $P$. falciparum during its early development in the vector; ideally, midguts from wild-caught anophelines should be examined $1-5 \mathrm{~h}$ pbm for round forms, 9-11 h pbm for retorts and 16-18 h $\mathrm{pbm}$ for ookinetes. Research on the stages of the parasite which are present within $30 \mathrm{~min}$ 


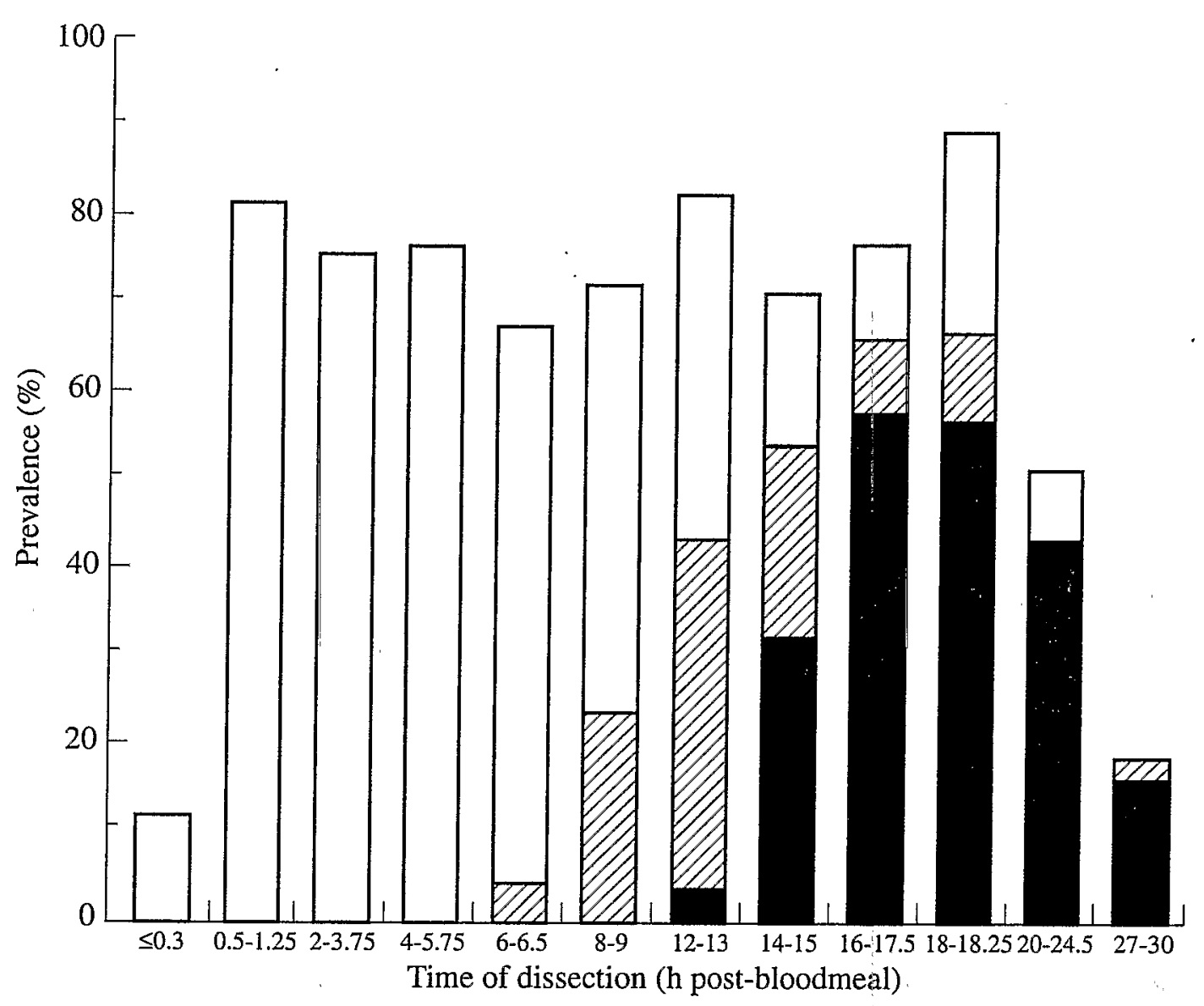

Fig. Prevalence of midgut infections with the round forms ( $\square$ ), retorts (四) and ookinetes ( $\square$ ) of Plasmodium falciparum in anopheline mosquitoes fed on one of four volunteers. The results are shown for 12 periods from 0.3 to $27-30 \mathrm{~h}$ post-bloodmeal, at which eight, $21,61,37,18,28,28,31,42,17,44$ and 16 mosquitoes were dissected.

of the infective feed should not be based on detection of Pfs-25 protein.

If the immunofluorescent technique is used on the intact walls of midguts removed from anophelines $40-56 \mathrm{~h}$ after an infective feed, intermediate stages between ookinetes and young oocysts may often be observed in contact with the walls. The significant decrease in the percentage of anophelines apparently infected after $20 \mathrm{~h}$ may simply be due to ookinetes leaving the lumen of the midgut and penetrating the midgut epithelium from $20 \mathrm{~h}$ onwards.

The prevalences and intensities of infection with round forms, retorts and ookinetes were also determined in 168 mosquitoes (An. gambiae s.s., An. funestus or $A n$. nili) fed on one of the four gametocyte carriers, an 18-year-old volunteer, over a period of 17 days. No asexual stages could be detected in the peripheral blood of the volunteer at the start of the study but screening of a thick smear of $5 \mu \mathrm{l}$ blood did reveal $41 P$. falciparum gametocytes $(8.2 / \mu \mathrm{l})$ of which 10 were microgametocytes. Although the prevalences of infection with round forms or ookinetes were higher for $A n$. gambiae and $A n$. funestus than for $A n$. nili (Table 1), this may be because $A n$. nili takes a relatively small bloodmeal, and not because $A n$. nili is less susceptible to infection by the same inoculum. The smaller meal taken by $A n$. nili may also explain why this species is usually found to have relatively low sporozoite indexes.

In each of the three anopheline species investigated, both the prevalence of infection and the intensity of infection tended to decrease as the malarial parasites developed ( $\mathrm{Ta}$ bles 1 and 2). Most round forms (90\% of 
TABLE 1

Prevalence of midgut infections with the round forms, retorts and ookinetes of Plasmodium falciparum in anopheline mosquitoes, after one bloodmeal on a gametocyte carrier

\begin{tabular}{lccc}
\hline Species & Round form & \multicolumn{1}{c}{ Retort } & \multicolumn{1}{c}{ Ookinete } \\
\hline Time of dissection (h post-bloodmeal) & $0.5-4.5$ & $8-13$ & $15-18$ \\
PREVALENCE (\% of dissected mosquitoes) & & & \\
An. gambiae & $83(19 / 23)$ & $89(16 / 18)$ & $62(13 / 21)$ \\
An. funestus & $80(12 / 15)$ & $43(3 / 7)$ & $60(3 / 5)$ \\
An. nili & $74(25 / 34)$ & $32(6 / 19)$ & $54(14 / 26)$ \\
\hline
\end{tabular}

TABLE 2

The intensities of infection with the round forms, retorts and ookinetes of Plasmodium falciparum in anopheline mosquitoes, after one bloodmeal on a gametocyte carrier

\begin{tabular}{|c|c|c|c|}
\hline Species & Round form & Retort & Ookinete \\
\hline Time of dissection (h post-bloodmeal) & $0.5-4.5$ & $8-13$ & $15-18$ \\
\hline \multicolumn{4}{|c|}{ MEAN (S.D.) INTENSITY (no. of forms/infected mosquito) AND [no. of parasites observed] } \\
\hline An. gambiae & $3.10(2.35)[59]$ & $2.25(1.34)[36]$ & $2.78(1.88)[36]$ \\
\hline An. funestus & $3.50(2.15)[42]$ & $2.67(2.08)[8]$ & $1.00(0.00)[4]$ \\
\hline An. nili & $2.56(1.39)[64]$ & $1.67(0.52)[10]$ & $1.79(1.19)[25]$ \\
\hline
\end{tabular}

those in $A n$. gambiae and $70 \%$ of those in $A n$. nili) of the wild strain of $P$. falciparum from the volunteer apparently developed successfully into ookinetes. This success is far better than that observed by Vaughan et al. (1992, 1994), when they fed the G3 strain of $A n$. gambiae, through a membrane, on the NF54 strain of $P$. falciparum. In this experimental. system, there were 40 - and 316-fold decreases in parasite numbers in the transition from the macrogametocyte to the ookinete stage.
V. ROBERT*
G. LE GOFF
ORSTOM (Institut Français de Recherche Scientifique pour le Développement en Coopération) and OCEAC (Organisation de Coordination pour la Lutte contre les Endémies en Afrique Centrale), P.O. Box 288, Yaoundé, Cameroon

L. C. Gouagna

OCEAC and University of Yaoundé I, P.O. Box 288, Cameroon

\section{SINDEN \\ J. KIEBOOM \\ R. KRONEMAN \\ J. P. Verhave}

Department of Medical Parasitology, University of Nijmegen, P.O. Box 9101, $6500 \mathrm{HB}$ Nijmegen, The Netherlands

\section{Received 30 fuly 1997, Revised 25 September 1997, Accepted 29 September 1997}

\footnotetext{
* Present address: ORSTOM, Laboratoire de Paludologie, P.O. Box 1386, Dakar, Senegal. E-mail: vincent.robert@orstom.sn; fax:+221832 1675.
} 


\section{REFERENCES}

Chege, G. M. M. \& BeIER, J. C. (1994). Foumal of the American Mosquito Control Association, 10, 419-422. Garnham, P. C. C. (1966). Malaria Parasites and other Haemosporidia. Oxford: Blackwell Scientific.

Meis, J. F. G. M., Wismans, P. G. P., Jap, P. H. K., Lensen, A. H. W. \& Ponnudurai, T. (1992). Acta Tropica, 50, 227-236.

Robert, V., Le Goff, G., Essong, J., Tchuinkam, T., FAas, B. \& Verhave, J. P. (1995). American fournal of Tropical Medicine and Hygiene, 52, 366-369.

VAughan, J. A., Noden, B. H. \& BeIER, J. C. (1992). Fournal of Parasitology, 78, 716-724.

Vaughan, J. A., Noden, B. H. \& BeIER, J. C. (1994). American Fournal of Tropical Medicine and Hygiene, $51,233-243$. 
VOLUME 92 NUMBER 1 IANUARY 1998

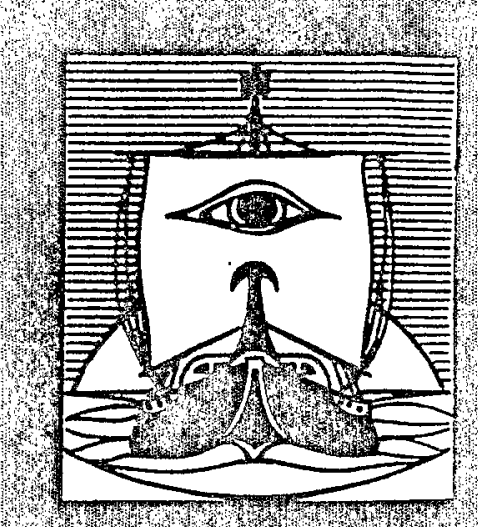

ANNALS OF
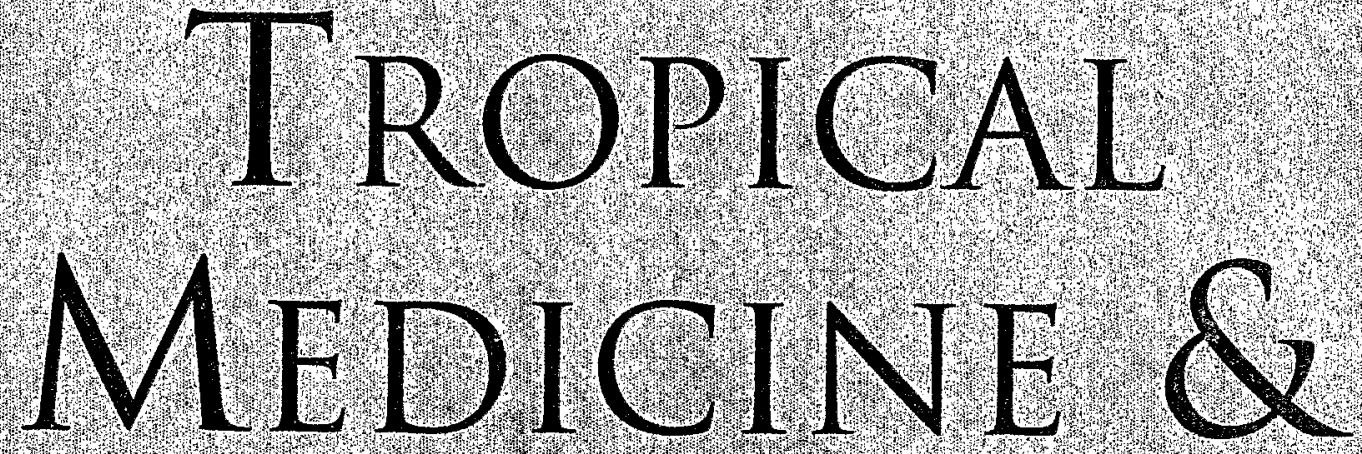

PARASITOLOGY

Published for the Itverpool scho ol of tropical Medicine

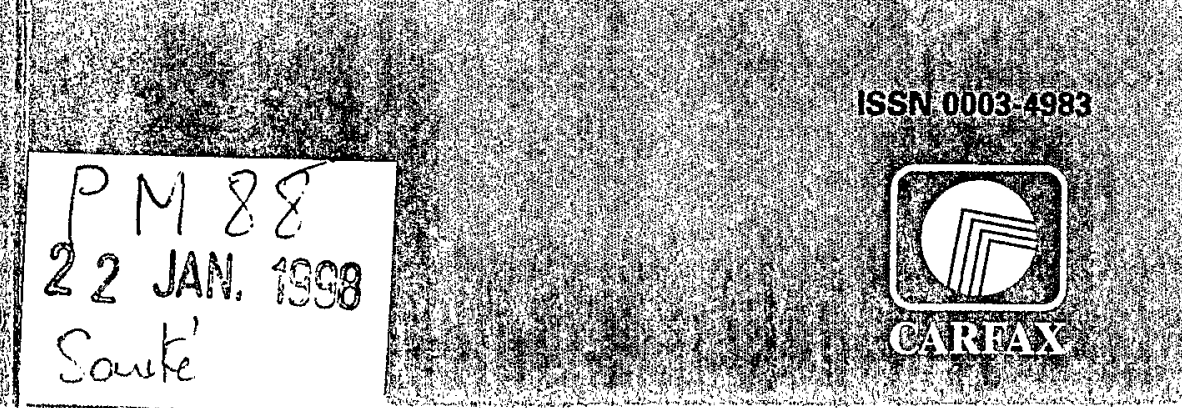

